\title{
Addressing the 'Citizenship Assumption' in Critical Pedagogy: exploring the case of rejected female sub-Saharan African asylum seekers in Malta
}

\author{
MARIA PISANI \\ Faculty of Education, University of Malta
}

\begin{abstract}
The degree to which an individual can or cannot confront domination is determined by his or her place within the social relations of production, the hegemony of ideological beliefs, including patriarchy and other cultural constructions, and institutional rules, regulations, and practices. These interactions are also shaped by the ways in which members of specific social groups understand, perceive, and act in, through, and on, their reality. This article considers the Maltese context, and the case of sub-Saharan African (SSA) female asylum seekers whose request for asylum has been rejected. The article aims to provoke a critical re-evaluation of the adult education and critical pedagogy literature, and calls for an epistemological shift in the way we theorise the non-citizen within the nation state. The article argues that the 'rejected' status limits the possibilities to speak unto power and to mobilise for transformative change. It concludes that a 'statist' hegemony is ubiquitous within critical pedagogy literature, wherein 'citizenship' is assumed.
\end{abstract}

\section{Introduction}

Critical pedagogy is grounded in the belief that every individual possesses the ability to produce knowledge and to confront domination in an effort to bring about transformative change (Darder et al, 2009). But to what degree does this principle consider the realities of those who are discursively constructed as 'illegal' and essentially positioned outside of the law? The analysis presented in this article forms part of my doctoral research and aims to locate transformative pedagogy within the day-to-day realities experienced by sub-Saharan African (SSA) rejected female asylum seekers in Malta. Located in the centre of the Mediterranean, south of Sicily and north of Libya, Malta (and the sister islands of Gozo and Comino), is the smallest of the European Union (EU) member states, with a population of just over 400,000. This article seeks to position critical pedagogy as a political discourse and practice (Giroux, 1992). It does so by drawing attention to the importance of contextual analysis that is attentive to power relations and the production of knowledge. Specifically, the article questions the notion of 'rights' in relation to irregular migration. The critical analysis presented in this article provides insights into how the dominant social order is maintained, in particular through the construction of the 'illegal' person, embodied in the SSA rejected female asylum seeker. Despite their strengths and resilience, SSA rejected female asylum seekers are forced to live in fear at the margins of Maltese society, excluded discursively, materially, and legally. This latter point not only raises questions as to the degree to which a rejected asylum seeker may be able to confront domination, but also highlights the barriers critical pedagogists must confront in developing a meaningful transformative pedagogy and spaces for progressive work. The article concludes by calling for an epistemological shift in the way the non-citizen is theorised within the nation state. 


\section{The Right to Rights?}

The degree to which the nation state still wields power has been a bone of contention within academic debate for some time now. Sassen $(2008$, p. 1) for example, has argued that we are now in the throes of an 'epochal transformation' experienced as globalisation, wherein the nation state has played a central role in enabling the shift towards 'denationalization', in particular within the domain of economic globalisation and within the human rights regime. Mayo (2010) on the other hand, has argued with equal tenacity that any suggestion that the nation state, within the contemporary neoliberal scenario, is no longer a key player is a 'myth'. I align myself with the latter, and will explore the situation in the Mediterranean at the periphery of the EU, in order to support this argument.

The free movement of persons is now a fundamental right guaranteed to EU citizens, capturing perhaps the separation of citizenship from the nation state, as denoted in terms such as 'post-national citizenship' (Sassen, 2006). However, the eradication of internal borders has come at a price as the security around external borders has increased. At the time of writing this article, the new flows of migrants fleeing the unrest in North Africa has conflicted with the desire for open borders, as EU ministers have met and agreed to roll back the Schengen Agreement and to tighten border controls (Euronews, 2011). What has been termed as 'Fortress Europe' has become increasingly restrictive for non-EU nationals, in particular non-Europeans (Joppke, 1998; Castles \& Miller, 2003).[1] De Haas has argued that African migration to Europe is 'fuelled by a structural demand for cheap (irregular) migrant labour [yet] obscured behind a series of discursive strategies politicians and states use ... which seems to justify the de facto exclusion and marginalization of irregular migrants through restrictive immigration law and border control' (de Haas, 2008, p. 15), and Malta is no exception (Suban, 2010).

Indeed, 'Fortress Europe' has been consistent in its attempts to prevent the 'unwanted' from making their way to the mainland. The Dublin II Regulation [2] ensures that those who manage to reach the EU will remain at the periphery rather than make their way to the richer nations of Northern Europe. In August 2008, the Italian Prime Minister, Silvio Berlusconi, and the Libyan national leader, Colonel Muammar al-Gaddafi, signed the Treaty on Friendship, Partnership and Cooperation between Italy and Libya. The treaty put to rest the disputes related to colonialism, at a considerable cost to Italy, which committed to building basic infrastructure for a total of $\$ 5$ billion, the annual expenditure amounting to $\$ 250$ million over 20 years (Ronzitti, 2009). More relevant to this article however, is Article 19 of the treaty that committed both parties to collaborate in the fight against 'illegal immigration' - in particular at sea - through bilateral and regional plans. Libya is a signatory to all key human rights treaties, with the exception of the 1951 Convention on Refugees, as well as being party to the 1981 African Charter on Human and People's Rights, which contains provisions on the treatment of foreigners. Notwithstanding the accusations of human rights violations levelled against Rome [3], the Government of Malta (GoM) was quick to support Italy's forced repatriation policy. The deputy prime minister and minister for foreign affairs stressed that strong support for this policy is in the Maltese 'national interest' (Stagno-Navarra, 2010). Not to be outmanoeuvred, the leader of the main opposition party, the Malta Labour Party (MLP), also supported the policy, agreeing that 'immigrants should be sent back to Libya immediately' (Sansone, 2009) and that 'he had not seen a humanitarian crisis in Libya with regard to migrants. Nor had he seen mainstream reports on migrants' conditions in Libya' (The Sunday Times, 2010). Rhetoric was fierce and steadfast as politicians scrambled to be seen to be taking a strong stand against illegal migration, reinforcing and complementing racist and xenophobic discourse and kowtowing to the far right oratory. In July 2010 events took an even stranger twist when 55 migrants on a boat within the Maltese search and rescue area were allegedly divided into two boats. The Armed Forces of Malta (AFM) claimed that 28 migrants were rescued and taken to Malta, whilst 27 'voluntarily' returned to Libya on a Libyan patrol boat. The UN Refugee Agency (UNHCR) and the Jesuit Refugee Service in Malta (JRS Malta) were quick to express concern at these developments; a UNHCR spokesperson disputed the AFM voluntary repatriation claims as 'not credible and scarcely realistic' (Stagno-Navarra, 2010). It would appear that the GoM went one step further, not only in supporting the Libya-Italy pact, but in somehow 'piggybacking' on the treaty. Such actions raise serious concerns as they would appear to have been in conflict with the principle of non-refoulement and in contradiction to Article 3 of the European Convention on 
Human Rights, which prohibits torture and 'inhuman or degrading treatment or punishment'. The onset of the 'Arab spring' and the crisis in Libya during 2011 saw an end to the push-back policy. As conflict within Libya heightened, and the authoritarian rule appeared to crumble, it apparently was no longer acceptable to 'outsource' European border control to a political tyrant with an abysmal human rights record (Noll \& Giuffré, 2011). As the violence escalated, and Ghadaffi once again became the pariah of the West, the treaty essentially collapsed and SSA asylum seekers began fleeing the violence, with a number of them arriving in Malta.

EU member states may well have 'denationalized', but only at a regional level. Certainly, the GoM has adjusted national institutional apparatus and adopted a market economy in line with the EU's declared requirements, as well as embracing economic globalisation (Pirotta, 2005), but it has not relinquished its sovereignty in protecting its borders. Clearly, the rights of undocumented migrants, recognised and protected under international law, are discounted. Herein one can also locate the paradox of neoliberalism and the liberal democratic state: the fervour for the free movement of capital, goods, and information has been met with an equally determined desire to close borders and restrict the movement of the world's poorest. As Slavoj Žižek rightly argues 'in the much celebrated free circulation opened up by global capitalism, it is 'things' (commodities) which circulate freely, while the circulation of 'persons' is more and more controlled' (2004, p.34).

\section{The Elephant in the Room}

The presence of irregular migrants has become the elephant in the room, a presence that all governments of EU member states are aware of, but which few are prepared to address for fear of being punished at the ballot box. There are between 4.5 and 8 million irregular migrants working in the EU (European Parliament, 2009), and yet, the Stockholm Programme, which sets out the key political priorities informing EU immigration policy and the legislative process between 2010-2014, remains silent on the rights of irregular migrants who cannot return to their country of origin (Gebhardt, 2010). The situation is further aggravated by the present financial crisis wherein, at times of financial insecurity, irregular migrants are often the scapegoats in explaining the national woes. And yet, despite their irregular status, migrants continue to meet the labour markets demand for unskilled labour and to contribute in a variety of ways to the host society (de Haas, 2008). Notwithstanding the integration of EU migratory policies, different EU member states have responded to the challenges of irregular migration in different ways. Indeed, the business of migration management remains in the control of the nation state, and the process of developing the 'Common European Asylum Policy' appears to have reached an impasse, as different member states flex their sovereign muscle and increasingly 'go it alone'. Given such disparities, the lived experience of migrants within the EU is, to a certain degree, determined by their geographical location, and the socio-political and historical context of the host society.

\section{Malta, the Carceral Archipelago}

Government statistics generally recognise the year 2002 as the onset of boat arrivals carrying SSA asylum seekers to Malta. Statistics presented by Eurostat indicate that in 2009, Malta received the largest per capita number of asylum applicants (Albertinelli, 2010). The vast majority of asylum seekers arriving in Malta originate from SSA and their arrival has been associated with two distinct, but interrelated outcomes. The first is the surfacing of nationalist discourse, the ascendance of farright political parties, increased xenophobia, Islamophobia, and racism.[4] The second is related to a hard-line policy response, infused with 'national security' discourse. For example, the GoM has asserted its sovereignty in implementing a mandatory detention policy for all asylum seekers, extending to an 18 month duration for rejected asylum seekers. This is despite the fact that:

The mandatory detention legal regime applied to unauthorized arrivals and asylum seekers does not seem to be in line with international human rights law. Migrants in an irregular situation are subjected to mandatory detention without genuine and effective recourse to a court of law. The length of their detention has not been clearly defined under law. (UN Working Group on Arbitrary Detention, 2010, p. 1-2) 
Whilst their request for asylum might have been rejected, many of these migrants come from countries where the possibility - and safety - of return is a contentious issue, for example, the case of persons claiming to come from Somalia, Eritrea, the Ivory Coast, or the Democratic Republic of Congo. In addition, Malta's lack of diplomatic relations and sub-Saharan African resident diplomatic representations renders the enforcement of return very difficult (Pisani \& Giustiniani, 2009). The end result is experienced as a state of limbo: no chance of leaving the carceral archipelago of Malta and travelling to mainland Europe, and no real opportunity of return.[5]

\section{Migration is a Gendered Process}

Gender is an integral part of the migration process that, with the impact of gender relations, roles and hierarchies, produces differential outcomes for women, from the point of departure, through transit, to arrival in the host society (Kofman et al, 2000). The legal status of SSA female migrants, further impacted by discursive understandings of their gender, race, and religious and cultural identity, provides the backdrop and justification for political rhetoric and subsequent policy development. Unreal representations have real consequences, and as such, rejected female SSA asylum seekers are at an increased risk of violation of their human rights. For example, in Malta, SSA women are constructed as the msieken [poor things], as veiled, dismissive, and subjugated, or as a source of moral panic, a diseased whore, hell bent on corrupting the Christian, Maltese moral standards. The following passage, citing a Maltese Trade Union leader is representative:

The first illegal immigrant who landed in Malta was St Paul. At least he gave us a Christian culture and left after three months. But what good are modern illegal immigrants doing us? They need food, clothing, education and social services and they want to give birth to their races among us ... now we have immigrant prostitutes (prostituti klandestini) who earn double the minimum weekly wage of a Maltese worker ... We cannot forget the dangers of undetected diseases which may spread among the population. (cited in iCare, 2005)

Such dehumanising discourse justifies the need, not only to 'protect' the Maltese citizens from the dangerous and corruptive 'other', but also justifies the substandard conditions they are expected to live in. The conditions in the detention centres in Malta were found to be particularly detrimental to the health and safety of female asylum seekers, as they were exposed to infectious diseases (acutely dangerous for pregnant women) and sexual and physical violence (MSF, 2009; United Nations, 2010). Upon release from detention, their situation is unlikely to improve a great deal, as rejected female asylum seekers are prone to experience barriers to basic services (including access to adequate housing, food, and healthcare) and do not receive social assistance (as a rejected asylum seeker, they cannot depend on the state for protection and the provision of social entitlements) (Pisani \& Azzopardi, 2008; JRS Malta, 2010). The following narrative captures this situation:

They want me to die in poverty. Racism, discrimination and unnecessary deportation are my greatest worries here. ... My fear is that I don't have a future here in Malta because they don't have a plan for me and that I have been abandoned like every other African who came from West Africa. (Cardona, 2010, p.149)

Such relations of inequality also define the conditions of entry for rejected female asylum seekers into the local labour force. Rejected female asylum seekers are, all too often, engaged in low-wage, exploitative terms of employment. Interestingly, the GoM has introduced an unusual policy in the regularisation of employment for rejected asylum seekers, in providing for the possibility to work in a regular manner. However, whilst her employment may be regularised, her legal status is not, and as such she continues to face the possibility of forced return. However, irrespective of the number of National Insurance contributions, rejected female asylum seekers do not qualify for unemployment benefit, nor can they benefit from sickness benefits or child allowance. Rejected female asylum seekers are 'outlaws' in as much as they fall outside the law and its protection (CoE, 2007). Whilst Malta's legal framework has transposed the employment elements of the Race Equality Directive, crucially:

the directive does not cover difference of treatment based on nationality and is without prejudice to provisions and conditions relating to the entry into and residence of third-country nationals 
and stateless persons on the territory of Member States, and to any treatment which arises from the legal status of the third-country nationals and stateless persons concerned'. (Council Directive 2000/43 / EC, Article 3[2]) Indeed, as others have argued, the directives fail to make a substantial difference to the experiences of undocumented migrants (including rejected asylum seekers) (ENAR, 2005).

The active regularised employment of rejected female asylum seekers in Malta not only problematizes the dichotomised legal/illegal migrant discourse, but also furthers the need to reframe the citizenship debate since it clearly figures so prominently in the giving and denial of basic rights. In the case of rejected female asylum seekers, exclusion and discrimination is formally sanctioned.

Patriarchal, racist, statist stereotypes abound, the regimes of discourse and power are inscribed on the body, reconstructing the subject (Foucault, 1977). And so, 'she' is 'black', 'rejected', an 'illegal immigrant'. It is here that we begin to see how the intersectionality of inter alia gender, race, class, and legal status plays out: where the fear of deportation further restrains the possibility to access rights or report violence, exposure to abuse and exploitation, and life is experienced at the margins of society, marked by isolation and poverty. The following extract from a rejected female asylum seeker's narrative captures this notion well:

This is a ghetto, but even in the ghetto there is privacy; but here we are just piled up in one small room as if we were not humans. But still we have to manage because we can't talk, whatever they say is what we do ... the place is not hygienic for children to live in. But we can't talk because we are the ones begging. (Cardona, 2010, p. 149)

The political clout of the 'illegal' other is nonexistent, the possibilities of exercising political agency are small, defined by her social reality that is experienced as an individual, but constituted at the political level. The will to fight is suppressed, the body is rendered docile. What are the pedagogical implications of such a reality?

\section{Citizens First, Human Beings Second}

Any perceived threat to the nation state is, of course, understood as a threat to its citizens. Within a liberal democracy, state power ultimately depends on its relationship with its citizens. Thus, whilst state-citizen legitimacy is bound by the ability to ensure economic opportunities for its citizens, citizens may also expect:

\footnotetext{
the state to ensure territorial security, provide a certain level of public services, protect their political rights, or preserve the cultural character of the nation. These more overtly political, geographical, and cultural aspects can go beyond and can even contradict the imperatives of capital accumulation. (Purcell \& Nevins, 2005, p. 212)
}

Thus, the nation state is compelled to protect its citizens against any perceived threat, retaining control over state borders, and, as will be considered later, policing 'membership' (Croucher, 2004). Indeed, as was illustrated above, recent developments in the Mediterranean demonstrate, in no uncertain way, the inherent contradiction that exists between the human rights framework and nation states' claims on controlling borders, and how nation states are asserting their lawful claim to protect their borders (Benhabib, 2004). Thus, whilst nation states may have the power to, and indeed do grant human rights, they also possess the power to regulate and curb them. Of course, irregular migration is not exclusive to Malta, or indeed to the EU. Indeed, there an estimated 30-40 million irregular or undocumented migrants worldwide, and as long as persons are in need of protection, and as long as disparate economic opportunities continue to divide the have from the have-nots, people will continue to move, too many of them beyond the protection of a state or the international human rights law (International Council on Human Rights Policy, 2010).

The example of Malta, outlined above, illustrates just some of the implications of being an irregular migrant. Rejected female asylum seekers are not citizens of the state, nor are they (by default) citizens of the EU. Citizenship formally assigns the equality of rights of all citizens within a political community; membership of the 'nation' is denoted by the status of citizenship, which conveys rights and duties. Citizenship thus represents a state-sanctioned form of discrimination. This is a situation that critical pedagogists cannot continue to ignore. 


\section{The National Way of Being is not the Natural Way of Being: implications for a critical pedagogy}

In order for a government to stand any chance of re-election, the state must ensure that it at least appears to be marching to the beat of the electorate's drum. Protecting the citizens is premised on the normality of the common sense notion of citizenship and the state. Non-citizens have no say in these decisions, rejected asylum seekers even less so, and yet political inclusion is essential in securing social justice and rights.

This 'statist' hegemony is ubiquitous, including within critical pedagogy discourse, wherein 'citizenship' is assumed, as is the notion of the level playing field in the eyes of the law. However, as has been illustrated in the case of rejected female asylum seekers in Malta, despite the intersectionality of race, ethnicity, and gender (amongst others), citizenship is the root of exclusion and subordination. Indeed, critical pedagogists may have been complicit in the creation of the social schism: citizens and non-citizens, those with rights (and a right to rights), and those without. Over the past few decades the intellectual landscape has shifted, the feminist and post modern critique has influenced a movement away from the macro, to the micro; discussions on class and patriarchy have been eclipsed by the new emphasis on cultural identity and difference (Ledwith, 2009). Citizenship, that which delineates an imagined community, but which has very real material consequences, is generally assumed. Take for example the 1997 Hamburg Declaration on Adult Learning, wherein it is declared that:

Adult education thus becomes more than a right; it is a key to the twenty-first century. It is both a consequence of active citizenship and a condition for full participation in society. (UNESCO, 1997)

One may note that whilst adult education is advanced as a 'right', citizenship is assumed as a condition for full participation. That persons may be excluded from this 'right' is not considered. Darder et al (2009) argue that critical pedagogy is fundamentally committed ... to the empowerment of culturally marginalized and economically disenfranchised students' (p. 9). But does this go far enough? Clearly, many of the problems rejected female asylum seekers have to deal with on a daily basis are directly related to their lack of legal status: their 'illegality'. Likewise, their ability to respond and to speak unto power is also limited due to their irregular status. We cannot assume otherwise. Citizenship embodies a regime of truth (Foucault, 1977), that which has demarcated, a priori, the truth, and how that truth should be regulated. Thus, as we have advanced in our own theoretical frameworks, and moved on to note the multiple sites of oppression, almost by rote ticking off the 'standard' list (class, gender, disability, race, etc.), equal rights in the eyes of the law, in other words citizenship, is taken for granted. I call this the 'citizenship assumption'. In other words, the way we have come to consider and pursue social justice within critical pedagogy has been framed within sovereign structures. As Parker and Brassett (2005) note, democracy cannot perform the task of justice since it is subsequent to the demarcation of the 'national community'. Those persons thus excluded from this demarcation are consequently also excluded from taking control of their 'destiny via democratic processes' (p. 239). And here we see the limitations of critical pedagogy and the possibilities of transformative action in advocating for a democratic process, paradoxically, within a 'national' democratic space from which rejected female asylum seekers, among others, are excluded.

\section{Can the Rejected Female Asylum Seeker Speak?}

The provision of adult education as a transformative pedagogy must necessarily expose the hidden, and confront the taken for granted. Critical pedagogists have a responsibility to expose the hegemonic processes within society. Gramsci (cited in Mayo, 2010) maintained that one must first look at the relationship between the state and civil society in order to understand the way power in Western capitalist social formations operate as a process of social control in the interests of the ruling class, thereby securing the hegemonic arrangements and maintaining the status quo (Darder et al, 2009). The concept of hegemony is also employed as the basis for a political strategy that aims to establish an alternative hegemony that does not serve to maintain the oppressed in a subordinate position (Buttigieg, 1991). 
The developments that are sketched above provide an alternative space to consider and develop Gramsci's conceptualisations of state and civil society. Whilst Gramsci often recognises the international context, his notion of civil society is understood in relation to the state (Ives, 2009). The degree to which this conceptualisation lends itself to contemporary debate of international civil society' or 'global citizenship' has been discussed elsewhere (see for example, Gill, 2003; Ives, 2009) and will not form a part of this debate. Suffice to note however, that, despite the transnational element of migration, and indeed its roots in the neoliberal capitalist framework, the nation state and sovereignty still holds court. This is no more apparent than in the policy development and political discourse that accompanies the security and protection of national borders. I have also demonstrated how the state-citizen relationship cannot be reduced to the perpetuation of capitalism, since ultimately it is the citizen who is the 'kingmaker'. It is this latter point that has important significance, not only for the development of a critical pedagogy that is attentive to power relations, but also to the possibilities of political mobilisation and resistance.

The decision to resist, and the possibility of resistance, is directly related to legal status, and goes beyond the social meanings assigned to 'categories' of persons such as 'race' or 'gender', or indeed economic factors. Rejected female asylum seekers are not citizens, they do not have a vote, they are officially excluded by the state, and this is sanctioned - or actively encouraged - by the 'citizens', the 'national popular', who also form the majority. It is at the point of convergence, where sovereignty, democracy, and the will of the people meet, that rejected female asylum seekers are squeezed out, and rendered voiceless and powerless. This is not to suggest that rejected SSA female asylum seekers do not demonstrate agency - the nature of their migration is testimony to their strength and determination in the face of often horrific conditions. Whilst much of the literature on critical pedagogy acknowledges obstacles to resistance (see for example Darder et al, 2009), there is an implicit assumption that, in principle, everyone has the 'right' to resist. Ideologically of course, I would support this notion; indeed it is premised on the notion that all human beings are equal, as established in the universal declaration of human rights. However, as demonstrated in this article, the 'right' to 'rights' cannot be assumed. In the case of rejected SSA female asylum seekers, the 'choice' to resist is not simply limited to social or material conditions, although of course, these factors constitute an important part, starting from life in SSA, through the migratory passage to Malta. Indeed, their existence at the margins has been the one constant companion throughout their migratory passage; their subordinate position has been sustained and intensified by the neoliberal framework. This includes women's location within the labour market (both in country of origin and destination), the fortification of borders that divides the rich from the poor, and the complicity of key institutions including the state, the community, and the family unit, which has led to the feminisation of poverty, and of migration (Kofman et al, 2000; Kabeer, 2003). All of these factors will come into play in impacting the possibility for resistance and curtailing political agency.

Citizenship is, of course, a social construct (a point that must be challenged and exposed). However the granting of 'citizenship' is a procedural, formal politico-juridical act that has unequivocal implications for political practice. In the past, as Joppke (2006) argues, workers, women, black people, and other disenfranchised groups were able to campaign for, and acquire, equal rights - in theory at least - because they were, a priori, assigned the status of 'citizen'. This is not a demand that rejected female asylum seekers can easily make. First and foremost, they simply do not have the political leverage (nor, at the time of writing, popular support) to bring about the changes necessary to improve their conditions. Second, any effort to do so - particularly within a micro-state such as Malta, characterised by hyper-surveillance - increases the risk of identification, retribution and/or deportation. Thus, the answer to the question, 'can the subaltern speak?' (Spivak, 1988), would have to be, 'in Malta, and at this point in time, not really, no ... or at least, not on her own'.

But here again I need to qualify my response. Whilst I make the argument that 'legal status' must be placed at the forefront of any discussion on political mobilisation, I do not want to fall into the trap of reductionism. As Croucher (2004) observes, there are a number of routes, beyond exercising one's vote, where individuals and groups can challenge and influence politics. The 'rejection' is a source of discrimination that rejected female asylum seekers may find difficult to challenge in an overt way for fear of exposure and (the perceived threat of) forced deportation, and it is therefore a barrier to political mobilisation. But it is of course not the only source of 
discrimination, as rejected female asylum seekers may experience exclusion on a number of grounds, including inter alia, class, race, and gender; legal status is intertwined throughout. As Reagon (1983) would caution, 'watch those mono-issue people' (1983, p. 360). Thus, a myopic and totalising notion of difference would fail to recognise how mechanisms of oppression are enmeshed in complicated ways (Mohanty, 2003), and impede the possibility of looking for issues that converge with those of others, and building coalitions. Within this complex and multifaceted location, there is fluidity. In line with the work of Giroux (1992) it can be argued that it is within this space that communities, in the plural, and made up of composite representations of identification and belonging, can interact to form alliances and connect.

\section{A Pedagogy of Advocacy}

Herein lays the challenge for critical educators in representing the rejected female asylum seeker, and giving true voice, rather than re-colonising her voice and perpetuating subjugation. Certainly, the only way one can authentically advocate on behalf of rejected female asylum seekers is to know them, and this can only be achieved through building trust and creating the conditions for, and engaging in, critical dialogue. Dialogue provides greater access to, and an understanding of, different communities and different worlds, and how individuals and communities interpret and give meaning to their worlds (Freire, 2001; hooks, 2003). Dialogue as pedagogy also makes it possible to problematise the situation of rejected female asylum seekers in Malta, wherein the obstacles are perceived as political, and as such, demand a counterhegemonic response that puts right the injustices of representation. Within this pedagogical process, representations are demystified and dominant ideologies, including the 'EU Fortress', the 'citizen', and the 'black illegal woman' amongst others, can be challenged. As such, rejected female asylum seekers can reposition themselves, alongside others, within the debate as producers of knowledge rather than the objects of untruths that are, all too often, taken on as 'common sense'.

\section{Conclusion}

The social construction of race, class, and gender are enmeshed with the international division of labour (Fischman \& McLaren, 2005). Indeed, the 'right' to migration is class-specific as international borders have become more and more restrictive. However, the granting of legal status (or not) is a national act, an official act, and in the case of rejected asylum seekers, it is the 'official' stamp of exclusion. In other words, excluding the notion of 'legal status' from our analysis limits our ability to understand and truly appreciate the lives of rejected female asylum seekers, and to recognise and create space for - and understand where barriers exist in - exercising agency, self determination, and resistance. Within this globalised world, where the neoliberal agenda and the demand for cheap labour continues to fuel migration, and nation states continue to protect their borders, critical pedagogists engaging in a pedagogy for transformative change cannot afford to make the 'citizenship assumption'.

\section{Notes}

[1] On 29 September 2008, the CoE, Commissioner for Human Rights issued his viewpoint on the trend towards the criminalisation of the irregular entry and presence of migrants in Europe. In the viewpoint, the Commissioner states: 'such a method of controlling international movement corrodes established international law principles; it also causes many human tragedies without achieving its purpose of genuine control'. (CoE, 2008)

[2] The Dublin II is an EU law that determines which member state is responsible for examining an application by asylum seekers seeking international protection under the Geneva Convention and the EU Qualification Directive. Generally speaking it is the state through which the asylum seeker first entered the EU. In other words, a woman who applied for asylum in Malta cannot request asylum in, or travel to, another member state. If she attempts to do so, and is apprehended by authorities, her fingerprints will be taken, and she will be returned to Malta. It is also appropriate to add that the Government of Malta has challenged the Dublin II on the grounds that the regulation places an 
unfair burden on Malta and similar southern member states, which, due to their geographical proximity to Africa, receive more asylum applications than other countries.

[3] At the time of writing, the European Court of Human Rights (ECtHR) was considering a landmark lawsuit against Italy filed by a group of asylum seekers originating from Somalia and Eritrea (Hirsi and Others v. Italy, Application no. 27765/09).

[4] The arrival of SSA asylum seekers has largely been perceived as a threat to Maltese society, and to the myth of cultural homogeneity. Societal discourse has reacted with the mobilisation of communal symbols (not least the 'nation's religion' or 'Christian values') and collective memories that subsume the heterogeneity and social hierarchy into some kind of larger collective, albeit imagined, national identity (Borg \& Mayo, 2006). For consecutive years, immigration has been considered to be either the top, or one of the top, concerns of the Maltese and the highest within the EU (European Commission, 2008). Resistance is well-documented in a growing number of national and international reports on racism and Islamophobia in Malta (see, for example, European Commission against Racism and Intolerance, 2008; Gauci, 2010).

[5] The majority of SSA asylum seekers reaching Malta did so by accident, and consider Malta as a transit country, their intention being to reach mainland Europe. (Falzon, 2007). Rejected asylum seekers do not have permission to leave the island (unless for return). However, the press regularly covers stories of rejected asylum seekers trying to leave the island using forged documents. In most cases the magistrate hands down a six-month jail sentence for trying to leave the country illegally (Johnston, 2010).

\section{References}

Albertinelli, A. (2010) Asylum Applicants and First Instance Decisions on Asylum Applications in Q1 2010. Brussels: Eurostat.

Benhabib, S. (2004) The Rights of Others: aliens, residents, and citizens. Cambridge: Cambridge University Press. http: / / dx.doi.org/10.1017/CBO9780511790799

Borg, C. \& Mayo, P. (2006) Learning and Social Difference. London: Paradigm.

Buttigieg, J. (1991) After Gramsci, Journal of the Midwest Modern Language Association, 24(1), 87-99. http: / / dx.doi.org/10.2307/1315027

Cardona, M. (2010) You Will Always Have the Poor among You: a report about poverty in Malta. Valletta: Centru Fidi u Gustizzja.

Castles, C. \& Miller, M. (2003) The Age of Migration: international population movements in the modern world. Basingstoke: Palgrave Macmillan.

Council of Europe (2008) It is Wrong to Criminalize Migration. http:/ / www.coe.int/t/commissioner/Viewpoints/080929_en.asp (accessed July 6, 2010).

Council of Europe (2007) The Human Rights of Irregular Migrants in Europe. https: / / wcd.coe.int/wcd/ViewDoc.jsp?id=1237553 (accessed July 4, 2011).

Croucher, S.L. (2004) Globalization and Belonging: the politics of identity in a changing world. Oxford: Rowman $\&$ Littlefield.

Darder, A., Baltodano, M.P. \& Torres, R.D. (2009) The Critical Pedagogy Reader, 2nd edn. New York: Routledge.

de Haas, H. (2008) The Myth of Invasion: the inconvenient realities of African migration to Europe. Oxford: International Migration Institute, University of Oxford.

de Sousa Santos, B. (2002) Toward a New Legal Common Sense: law, globalization, and emancipation. London: LexisNexis Butterworths.

European Commission (2008) Europeanbaromter 70. Brussels: European Commission.

European Commission against Racism and Intolerance (2008) Third Report on Malta. Strasbourg: Council of Europe.

European Network against Racism (ENAR) (2005) Response of the European Network against Racism (ENAR) Council Directive Implementing the Principle of Equal Treatment between Persons Irrespective of Racial or Ethnic Origin. 2000/43/EC.

http: / / cms.horus.be / files/99935/MediaArchive/pdf/DEC05_ENAR_ED_\%205yr_report.pdf (accessed March 21, 2011). 
Euronews (2011) EU Summit Spells the End of Schengen? http:/ /www.euronews.net/2011/06/25/eusummit-spells-the-end-of-schengen (accessed June 28, 2011).

European Parliament (2009) Europe to Penalise Employers of Illegal Immigrants. http: / / www.europarl.europa.eu/ sides / getDoc.do?language=en\&type=IMPRESS\&reference $=200901201 P R 46696$ (accessed July 6, 2011).

Falzon, M.A. (2007) Return Policy in the Mediterranean Region. Report of Survey among Irregular Migrants in Malta. Malta: International Organization for Migration.

Fischman, G.E. \& McLaren, P. (2005) Rethinking Critical Pedagogy and the Gramscian and Freirean Legacies: from organic to committed intellectuals or critical pedagogy, commitment, and praxis, Cultural Studies, 5(4), 425-447.

Foucault, M. (1977) Discipline and Punish: the birth of the prison. London: Penguin.

Freire, P. (2006) Pedagogy of Hope: reliving pedagogy of the oppressed. London: Continuum.

Freire, P. (2001) Pedagogy of the Oppressed. New York: Continuum.

Gauci, J.P. (2010) Racist Violence in Malta: an overview of law and trends and compilation of experiences. Brussels: European Network against Racism.

Gebhardt, D. (2010) Irregular Migration and the Role of Local and Regional Authorities, in S. Carrera, \& S. Merlino (Eds) Assessing EU Policy on Irregular Immigration under the Stockholm Programme, pp. 15-17. Brussels: Centre for European Policy Studies (CEPS).

Gill, S. (2003) Gramsci, Modernity and Globalization. http:/ / www.internationalgramscisociety.org/resources/online_articles/articles/gillo1.shtml (accessed January 29, 2011).

Giroux, H.A. (1992) Border Crossings: cultural workers and the politics of education. New York: Routledge.

hooks, b. (2003) Teaching Community: a pedagogy of hope. London: Routledge.

Integraref (2008) Local Communities and Refugees: fostering social integration. Brussels: European Commission.

International Council on Human Rights Policy (ICHRP) (2010) Irregular Migration, Migrant Smuggling and Human Rights: towards coherence. Geneva: ICHRP.

Internet Centre Anti Racism Europe (ICARE) (2005, October 14) Union President Attacks Immigrants (Malta).

http:/ / www.icare.to/news.html\#UNION\%20PRESIDENT\%20ATTACKS\%20IMMIGRANTS\%28Malt a\%29 (accessed September 11, 2010).

Ives, P. (2009) Our Language Question: Gramsci, the state-system and global capitalism. http: / / www.psa.ac.uk/journals/pdf/ 5/2009/Ives.pdf (accessed February 9, 2011).

Johnston, W. (2010) Migrants Jailed for Escaping from Malta. http: / / www.timesofmalta.com/articles/view/20100130/local/migrants-jailed-for-escaping-from-malta (accessed April 3, 2010).

Joppke, C. (1998) Challenge to the Nation-State: immigration in Western Europe and the United States. New York: Oxford University Press.

Jesuit Refugee Service Malta (2010) A Report on a Pilot Study of Destitution amongst the Migrant Community in Malta. Malta: Advocacy Network on Destitution.

Kabeer, N. (2003) Gender Mainstreaming in Poverty Eradication and the Millennium Development Goals: a handbook for policy makers and other stakeholders. London: Commonwealth Secretariat.

Kofman, E., Phizacklea, A., Raghuram, P. \& Sales, R. (2000) Gender and International Migration in Europe. Oxford: Routledge.

Ledwith, M. (2009) Antonio Gramsci and Feminism: the elusive nature of power, Educational Philosophy and Theory, 41(6), 684-697. http:/ / dx.doi.org/10.1111/j.1469-5812.2008.00499.x

Mayo, P. (2010) Gramsci and Educational Thought, in P. Mayo, Antonio Gramsci and his Relevance to the Education of Adults, pp. 21-37. Chichester: Wiley Blackwell.

Mohanty, C.T. (2003) Feminism without Borders. Durham, NC: Duke University Press.

Medicins Sans Frontiers (2009) 'Not Criminals': Medicins Sans Frontiers exposes conditions for undocumented migrants and asylum seekers in Maltese detention centres.

http: / / www.aerzte-ohne-grenzen.at/fileadmin/data/pdf/reports/2009 / MSF_Report_Malta_2009.pdf (accessed January 22, 2011).

Noll, G. \& Giuffré, M. (2011) EU Migration Control: made by Gaddafi? http:/ / www.opendemocracy.net/ gregor-noll-mariagiulia-giuffr\%C3\%A9/ eu-migration-control-madeby-gaddafi (accessed July 5, 2011). 
Parker, O. \& Brassett, J. (2005) Contingent Borders, Ambiguous Ethics: migrants in (international) political theory, International Studies Quarterly, 49, 233-253. http: / dx.doi.org/10.1111/j.0020-8833.2005.00343.x

Pirotta, G.A. (2005) Public Enterprise Implications of Malta’s Entry into the European Union, Asia Pacific Journal of Public Administration, 27(2), 201-220.

Pisani, M. \& Azzopardi, A. (2008) The Odyssey of the Young Female Asylum Seeker: engaging critically on gendered forced migration, Forum21, 128-135.

Pisani, M. \& Giustiniani, A (2009) Programmes and Strategies in Malta Fostering Assisted Return to and Reintegration in Third Countries. Valletta: EMN.

Purcell, M. \& Nevins, J. (2005) Pushing the Boundary: state restructuring, state theory, and the case of U.S.Mexico border enforcement in the 1990s, Political Geography, 24, 211-235. http: / / dx.doi.org/10.1016/j.polgeo.2004.09.015

Reagon, B.J. (1983) Coalition Politics: turning the century, in B. Smith (Ed.) Home Girls: a black feminist anthology, pp. 356-368. New York: Kitchen Table, Women of Color Press.

Ronzitti, N. (2009) Treaty on Friendship, Partnership and Cooperation between Italy and Libya: new prospects for cooperation in the Mediterranean? (Analysis).

http: / / migrantsatsea.wordpress.com/ 2009/06/ 20/ analysis- $\% E 2 \% 80 \% 93-1$-june-2009-\%E2\%80\%93-thetreaty-on-friendship-partnership-and-cooperation-between-italy-and-libya-new-prospects-forcooperation-in-the-mediterranean (accessed October 6, 2010).

Sansone, K. (2009) Illegal migration.

http: / / www.timesofmalta.com/articles/view/20090512/local/opposition-backs-italy-policy-as-councilof-europe-objects (accessed August 26, 2010).

Sassen, S. (2008) Territory, Authority, Rights: from Medieval to global assemblages. Princeton: Princeton University Press.

Sassen, S. (2006) The Repositioning of Citizenship and Alienage: emergent subjects and spaces for politics, in K. Tunstall (Ed.) Displacement, Asylum, Migration, pp. 176-203. New York: Oxford Amnesty Lectures.

Spivak, G.C. (1988) Can the Subaltern Speak?, in C. Nelson \& L. Grossberg (Eds) Marxism and the Interpretation of Culture, pp. 271-313. Urbana: University of Illinois Press.

Stagno-Navarra, K. (2010) Leaving it in Neutral. http: / / archive.maltatoday.com.mt/2010/01/24/interview.html (accessed August 26, 2010).

Suban, R. (2010) Satisfying Malta's Labour Market Demands through Migration: a study. Valletta: European Migration Network.

Sunday Times (2010) Immigration: national interest comes first - Muscat.

http: / / www.timesofmalta.com/articles/view/20100919/local/immigration-national-interest-comesfirst-muscat (accessed September 19, 2010).

United Nations (2010) Report of the Working Group on Arbitrary Detention: mission to Malta. Geneva: United Nations.

UN Working Group on Arbitrary Detention (2010) Report of the Working Group on Arbitrary Detention on its Mission to Malta (19 to 23 January 2009). http:/ / www2.ohchr.org/english/bodies/hrcouncil/docs/13session/ A.HRC.13.30.Add2.pdf (accessed July 15, 2010)

UNESCO (1997) The Hamburg Declaration on Adult Learning. http: / / www.unesco.org/education/ uie/ confintea/declaeng.htm (accessed June 29, 2011).

Žižek, S. (2004) Iraq: the borrowed kettle. London: Verso.

MARIA PISANI works at the Faculty of Education, University of Malta and is a PhD candidate. Her research interests include: critical pedagogy; forced migration; undocumented irregular migrants; gender and migration; and adult education. Correspondence: maria.pisani@gmail.com 